Full Length Article

\title{
Thermodynamics analysis and performance optimization of a reheat - Regenerative steam turbine power plant with feed water heaters
}

\author{
S.O. Oyedepo ${ }^{a}$, B.A. Fakeye ${ }^{\mathrm{a}}$, B. Mabinuori ${ }^{\mathrm{a}}$, P.O. Babalola ${ }^{\mathrm{a}}$, R.O. Leramo ${ }^{\mathrm{a}}$, O. Kilanko ${ }^{\mathrm{a}}$, \\ J.O. Dirisu ${ }^{\mathrm{a}}$, M. Udo ${ }^{\mathrm{a}}$, U.K. Efemwenkiekie ${ }^{\mathrm{a}}$, J.A. Oyebanji ${ }^{\mathrm{b}}$ \\ ${ }^{a}$ Mechanical Engineering Department, Covenant University, Ota, Nigeria \\ ${ }^{\mathrm{b}}$ Mechanical Engineering Department, Bells University of Technology, Ota, Nigeria
}

G R A P H I C A L A B S T R A C T

Plot of Cycle Efficiency against Number of closed FWHs.

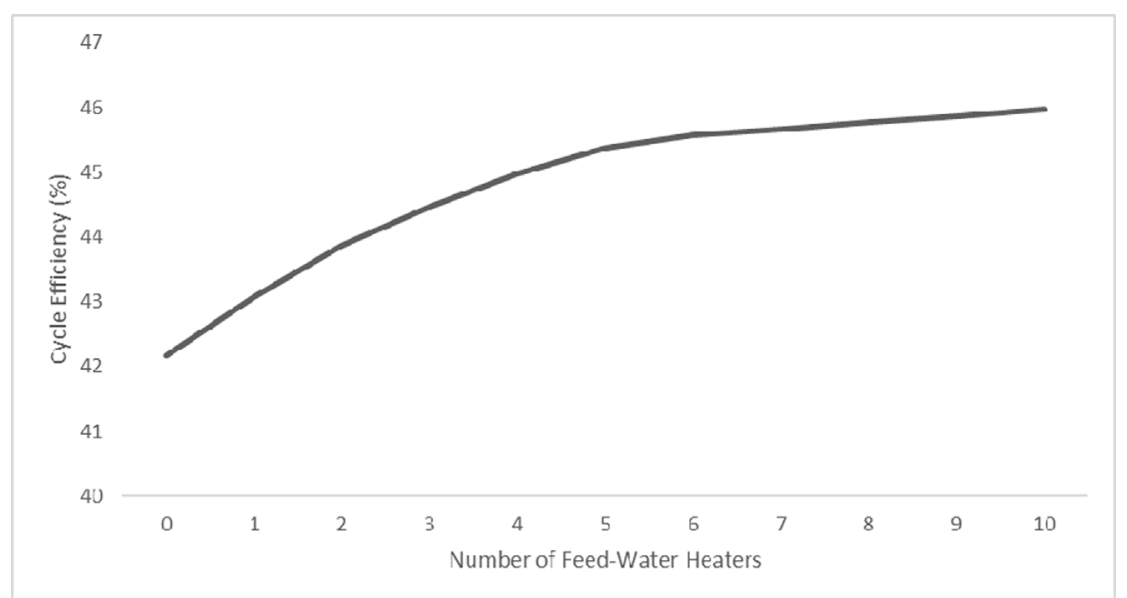

A R T I C L E I N F O

\section{Keywords:}

Cycle efficiency

Feedwater heater

Performance optimization

Specific steam consumption

Heat input

Heat rate

\begin{abstract}
A B S T R A C T
This study investigates the thermodynamics performance analysis of a reheat-regenerative steam power plant using CyclePad V2.0 software. The impact of closed Feedwater Heaters (FWHs) on the functionality indices of the selected power plant was examined. Results of the study show that as the number of closed FWH increases from one to ten, the thermal efficiency and boiler efficiency rise from $42.17 \%$ to $45.97 \%$ and $79 \%$ to $96.4 \%$, respectively. The fuel consumption, heat rejected to the condenser, heat rate, network output and heat input to the power cycle decrease from $9.697 \mathrm{~kg} / \mathrm{s}$ to $4.686 \mathrm{~kg} / \mathrm{s}, 209.32 \mathrm{~kJ} / \mathrm{kg}$ to $129.68 \mathrm{~kJ} / \mathrm{kg}, 8536.87 \mathrm{~kJ} / \mathrm{kWh}$ to $8318.48 \mathrm{~kJ} / \mathrm{kWh}, 152.22 \mathrm{MW}$ to $102.89 \mathrm{MW}$ and $361.11 \mathrm{~kJ} / \mathrm{kg}$ to $237.98 \mathrm{~kJ} / \mathrm{kg}$, respectively as the number of FWHs increased. On the contrary, specific steam consumption increases from $0.0234 \mathrm{~kg} / \mathrm{kWh}$ to $0.0370 \mathrm{~kg} / \mathrm{kWh}$. Moreover, fuel consumption decreases by $51.7 \%$ and the efficiency gain $(\eta)$ successively diminish with increment in the number of closed FWHs. Also, both enthalpy rise and temperature rise increase with increase in the number of closed FWHs. As the number of heaters increases, so is the total temperature rise of feed water $\left(\Delta t_{f w}\right)$, by regeneration, less becomes the heat added to water in the boiler, more becomes the mean temperature of heat addition, and more is the cycle efficiency. This result implies that a decrease in operating cost of the plant and
\end{abstract}

\footnotetext{
* Corresponding author.

E-mail address: sunday.oyedepo@covenantuniversity.edu.ng (S.O. Oyedepo).
} 


\begin{tabular}{llll}
\multicolumn{2}{l}{ Nomenclature } & \multicolumn{2}{l}{ Total enthalpy rise of feedwater $(\mathrm{kJ} / \mathrm{kg})$} \\
& & $\mathrm{T}$ & Temperature $\left({ }^{\circ} \mathrm{C}\right)$ \\
$\mathrm{h}$ & Enthalpy $(\mathrm{kJ} / \mathrm{kg})$ & $\dot{\mathrm{m}}$ & mass flow rate $(\mathrm{kg} / \mathrm{s})$ \\
$\mathrm{s}$ & Entropy $(\mathrm{kJ} / \mathrm{kgK})$ & $Q_{i n}$ & Heat input $(\mathrm{MW})$ \\
$\mathrm{W}_{\mathrm{t}}$ & Network output $(\mathrm{MW})$ & $\eta$ & Thermal efficiency $(\%)$ \\
$\mathrm{v}$ & Specific volume $\left(\mathrm{m}^{3} / \mathrm{kg}\right)$ & $\Delta t_{f w}$ & Total temperature rise of feedwater $\left({ }^{\circ} \mathrm{C}\right)$
\end{tabular}

environmental impacts can be achieved with an increase in the number of closed FWHs. Hence, this study establishes the importance of closed FWHs in revamping the performance of a steam power plant.

\section{Introduction}

Energy has become one of the main elements of economic and social development in the modern world, and access to reliable and affordable energy is essential for sustainable development [1]. Most of the energy consumption comes from fossil fuels, which accounts for $81.1 \%$ of the total energy consumption. Fossil fuels drive a large percentage of engines in power sectors. And a significant portion of $\mathrm{CO}_{2}$ emissions is generated from the fossil fuel-fired power plants. According to the International Energy Agency (IEA), global energy needs are expected to grow over the next decades with the domination of fossil fuels as the energy source [2]. As a result, emissions represented by $\mathrm{CO}_{2}$ are expected to increase sharply, and thus, its dramatic consequences [3]. The Intergovernmental Panel on Climate Change (IPCC) indicates that $\mathrm{CO}_{2}$ emissions need to be cut by a minimum of $50 \%$ to limit the average global temperature increment to $2{ }^{\circ} \mathrm{C}$ in 2050 [4].

A substantial amount of the world energy need is supplied from fossil fuels which are increasingly disappearing and damage the ecology in the world [5]. Due to the increasing awareness of the depletion of fossil fuel resources and environmental issues, intensive researches have been conducted to control the negative impacts of fossil fuels on ecological pollution [6]. Among the new strategies to eradicate this challenge is a replacement of fossil fuels by utilizing alternate energy sources like biodiesel fuel in an internal combustion engine $[7,8]$. Biodiesel became more and more attractive in recent years due to its potential to protect the environment by reducing $\mathrm{CO}_{2}, \mathrm{SO}_{2}, \mathrm{CO}$ and hydrocarbon (HC) emissions [9]. The discharge of $\mathrm{SO}_{2}$ in the combustion process of biodiesel is much lower than regular fossil fuel (diesel oil) because of the low sulfur content in it. Thus, the use of biodiesel instead of conventional diesel oil will effectively reduce acid rain. Moreover, $\mathrm{CO}, \mathrm{HC}$ and particulate matters will have less discharged because ester compounds in biodiesel contain oxygen promoting cleanburning. Hence, by employing biodiesel in an internal combustion engine results in a substantial reduction of HCs, aromatic hydrocarbons, CO, alkenes, aldehydes, ketones, and particulate matter $[10,11]$.

The utilization of power is one of the vital signs showing the developmental stages of countries and the living standards of communities. The most effective way to meet energy demand is to use energy more efficiently. Also, a well-designed energy system can make a significant contribution to sustainability. The growing global energy consumption and environmental situation have created an interest in the plant equipment efficiency and the optimization of existing thermal power plants [12]. This is purposely to develop efficient ways for energy generation and conservation that avoid the production of greenhouse gases that contribute to climate change [13,14]. Improving performance indices such as thermal efficiency of thermal power plant plays a fundamental role in reducing consumption of limited energy resources and environmental impacts $[15,16]$. Performance improvements in thermodynamic cycles for efficient production of a steam thermal power plant have become increasingly important in the actual worldwide sustainability context due to its implications of net incremental power output and investment cost savings [17,18].
Improvements in thermal efficiency through the incorporation of more advanced technologies as well as improved plant configurations can certainly decrease the carbon footprint of electricity generation on a per megawatt basis $[19,20]$. Based on this fact, analyses of power generation systems are of scientific interest and also essential for the efficient utilization of energy resources [21].

Engineering study and analysis of energy conversion systems are essential due to increasing global energy consumption, and the rising environmental restrictions, specifically in the carbon dioxide emissions issue [22]. Owing to their significant contribution towards power production, thermal power plants have a vital role to play in the development of a nation. Due to the shortage of power generation, every power generation system needs to be operated at a maximum level of efficiency. Thermal power plants' auxiliaries are not exempted from this condition to fulfil [23]. From thermodynamic perspective, Rankine cycle is an idealized thermodynamic cycle that predicts performance of steam power plants. The first stage in designing these power plants is the thermodynamic analysis of processes of Rankine cycle [24].

To achieve optimal performance of a steam power plant, numerous ways to utilize available energy more efficiently and extract more power from a current system are being considered by making several modifications [25]. Changes such as the incorporation of closed FWHs, reheaters, regenerator etc., are made with a view of augmenting the efficiency and improving other operating parameters such as quality of steam at the turbine exhaust. Once reheaters and feedwater heaters are in place, optimizing process parameters is essential to obtain maximum thermal efficiency for given boiler pressure, condenser pressure and steam temperature at the turbine inlet. Feedwater heating process increases the temperature of feed water at the channel to the boiler and the rise in feed water temperature lowers the heat requirement in a boiler for getting the desired state at the bay to a steam turbine. Thus, with less heat addition to the boiler, the cycle efficiency is shoot-up. Improving power plant efficiency could alleviate the negative effect of fossil fuel consumption on $\mathrm{CO}_{2}$ emission [26].

Various pragmatic steps adopted for improving the Rankine cycle performance indices have led to different versions of the reformed Rankine cycle, such as Reheat cycle, Regenerative cycle, etc. With reheat, there is a possibility of an increase in thermal efficiency that results in higher boiler pressure and yet avoids low dryness fraction of steam at the turbine exhaust [27]. The regenerative cycle has an advantage of increasing the feedwater temperature on its way back to the boiler in a feedwater heater [28]. The process of preheating air and water to improve overall cycle efficiency is used extensively in gas turbine and steam turbine power plants. In the case of the steam power plant, steam is extracted from various turbine stages through heat exchangers called closed FWHs to preheat feedwater before entering the boiler [29].

Numerous researchers have demonstrated exceptional efforts towards the study of effects of FWHs on performance improvement of a steam power plant. Srinivas et al. [27] analyzed the effect of ' $n$ ' FWHs on the performance of a steam power cycle with a generalized mathematical formulation. The optimum bled steam temperature ratio was 
found at 0.4 with single FWH at given working conditions. Results of the study showed that the maximum gain in the cycle efficiency obtained with the first FWH and the increment diminished with the addition of the number of heaters. The work examined the improvements in efficiency with increases in boiler pressure, turbine inlet temperature and furnace temperature. Wijaya and Widodo [30] carried out thermodynamic analysis and simulation of a $200 \mathrm{MW}$ steam power plant under the different operating condition of closed feedwater heaters using cycle tempo. The study showed that high-pressure heater (HPH) has the greatest influence on the performance of the plant because the highest increasing feedwater temperature occurred in HPH. Kumar and Sravanthi [31] investigated the roll of feedwater heaters to give the satisfactory thermal performance of a $120 \mathrm{MW}$ thermal power plant. In the study, the performance of the feedwater heaters was analyzed by finding the terminal temperature difference (TTD) drain cooling approach (DCA) and the temperature rise of the heaters. Almedilla et al., [32] conducted a performance evaluation of both open and closed types feedwater heaters of a coal power plant during full load using CATT 3 software. Result of the study showed that the performance of regenerative feedwater heaters proved that last stage heaters mostly encounter off the design and high-pressure heaters are the most efficient. Kushwaha and Koshti [33] investigated the performance analysis and off-design behaviour of FWH. The study showed that a change in exit temperature of feedwater was small for all the given cases of off-design conditions. Hence, the heat transfer rate increased with increasing the mass flow rate of feedwater.

Result of the study further revealed that changes in bled steam temperature did not appear to have a significant effect on the area distributions of FWH. Shabani et al., [34] evaluated the performance of feedwater pre-heaters of a $200 \mathrm{MW}$ steam power plant. The effect of leakage of condensates on the condenser was also investigated. The study revealed that though the first two LPHs (LPH1 and LPH2) had the lowest exergy efficiency, they exhibited the most significant effect on the efficiency of the cycle. The last two HPH and LPH (HPH6 and LPH4) had the highest heat exchange. As regard leakage along the route to the condensate of heaters, the most negative effect was due to the HP heaters. The study further showed that LPH1 and LPH2 had the most significant impact of leakages on the cooling tower. Almedilla et al., [35] assessed the performance of FWHs on the 405 MW Coal-Thermal Power Plant using performance indicators: terminal temperature difference (TTD), drain cooler approach (DCA) and temperature rise (TR) across heater. Results of the study revealed that the high-pressure feedwater heaters (HPHs) were significantly more efficient compared to the low-pressure feedwater heaters (LPHs).

In the area of modelling, simulation and optimization of FWHs, Álvarez-Fernández, et al., [36] simulated performance of closed FWHs in a nuclear power plant. Result of the study showed that the model developed and simulated has relevant applications in nuclear power plants, where the fluid flowing through the steam turbine is wet steam. Gupta et al., [37], developed a simulation model for performance evaluation of a feedwater system in a typical thermal power plant using Markov Birth-Death process and probabilistic approach. Performance evaluation of the feedwater system was carried out. Further, the optimum values of failure/repair rates for maximum system availability were as well determined. The findings of the study are beneficial to plant management to decide about the maintenance priorities of various subsystems of the system concerned in a thermal plant. Byregowda et al. [38] carried out modelling and simulation of a feedwater heater of a steam power plant systems. The study focused on one-dimensional modelling and simulation of low pressure closed feedwater heater using computational fluid dynamics (CFD) simulation software (Flownex SE). Result of the study showed that LPH increasingly gained the capacity to support both the efficient optimization of a given feedwater heater concept. Devandiran et al. [39] carried out analysis and performance optimization of coal power plant with FWHS using Heat and Mass Balance Diagram (HMBD) software. The study revealed that the overall efficiency of the power plant increased by $2.4 \%$. Moreover, the turbine heat rate and coal consumption reduced considerably by using a feedwater heater.

Researchers have carried out second law and economic analyses on the performance of FWHs. Pandey and Gogoi [24] carried out second law analysis on a reheat - regenerative vapour power cycle. The parametric study revealed that the cycle energetic and exergetic efficiencies increased with increase in pressure and temperature. This result was due to reduced energetic and exergetic losses at increased pressure and temperature. Dubey and Mishra [40] carried out energy and exergy analysis of a combined reheating-regenerative Rankine Cycle using entropy generation principle. Result of the study revealed that a large proportion of steam lost occurred in a steam generator, turbines and FWHs of the plant. However, boiler, HPT, IPT and superheater are found in the best performance in the study. The exergy efficiency of a steam power plant based Rankine cycle system was optimized by Elahifar et al., [41] using intelligent algorithms including bees, fireflies, and algorithm based on teaching and learning. Result of the study showed that exergy efficiency of the studied thermal power plant can be increased from $30.1 \%$ to $30.68047 \%, 30.70368 \%$, and $30.70369 \%$, by bees' algorithm, fireflies' algorithm and algorithm based on teaching and learning, respectively. Nsanzubuhoro et al., [42] investigated the Second law analysis of a fossil - geothermal hybrid power plant with thermodynamic optimization of the geothermal preheater. The study evaluated the energetic and exergetic effects of replacing a LPFWH with a geothermal preheater sourcing heat from a low-temperature geothermal resource. Vandani et al., [43] performed exergoeconomic analysis on a steam power plant in Iran and the effects of adding a new feedwater heater to cycle were investigated through second law and economic analysis.

The prime objectives of this study are to investigate the effects of increasing the number of closed FWHs on: (i) the performance parameters (power output, thermal efficiency, specific fuel consumption, specific steam consumption and heat rate) of reheat - regenerative steam power plant using cyclepad v2.0; (ii) the total enthalpy rise and overall temperature rise of feedwater in the reheat -regeneration cycle, and (iii) the boiler efficiency

\subsection{The concept of reheat - Regenerative system in thermal power plant}

Further to prevent the side effect of vapour condensation during steam expansion in a steam turbine, the simple steam power cycle is incorporated with a reheater. In this process, all the steam after a partial expansion in the turbine is brought back to the boiler, reheated by combustion gases and then fed back to the turbine for further expansion. In the reheat cycle, the steam is re-superheated (or reheated) at constant pressure in the boiler, and the remaining expansion of steam is carried out in the low pressure (L.P.) turbine [44]. As a result of the reheating step between the two turbines, the quality at the low-pressure turbine effluent is quite high. Reheat process improves the network output of the turbine, quality of steam at L.P turbine exit, which brings about a reduction in turbine blade erosion.

In the Rankine steam power cycle, the condensate at low temperature mixes irreversibly with hot water from the boiler, and this brings about a decrease in the cycle efficiency. To prevent such effect, the temperature of the feedwater is raised before it enters the boiler by extracting steam from the turbine at various locations. The process of using the bled steam to preheat the feedwater going into the boiler is called regeneration method, and the cycle is called regenerative cycle [45]. Regeneration does not only improve cycle efficiency but also provides a convenient means of deaerating the feed water to prevent corrosion in the boiler. It also aids restricting copious volume flow rate of the steam from turbine exit to condenser [46]. A modem steam power plant is equipped with both reheater and regenerator to enhance its performance and for effective fuel utilization [47]. 


\section{Materials and method}

\subsection{Study area}

Egbin power plant consists of 6 units of $220(6 \times 220 \mathrm{MW})$ reheat regenerative cycle. It is dual fired (gas and heavy oil) system with modern control equipment, single reheat and six stages regenerative feedwater heating [48]. Fig. 1 shows the flow diagram of the selected steam power plant containing six units. The design basis of each unit is a nominal 220 MW Reheat- Regenerative cycle. Each unit of the plant comprises of the following components: (i) Steam Generator or fossil boiler (FB) including an evaporator together with radiative, superheater, a reheater, an economizer, and an air preheater which is supplied by natural gas (NG); (ii) Steam Turbine - is the impulse type, tandem-compound, double flow reheat, condensing tube, with maximum continuous rating of $220 \mathrm{MW}$, speed $3000 \mathrm{rpm}$, initial steam pressure $12.5 \mathrm{MPa}$, initial steam temperature $538{ }^{\circ} \mathrm{C}$, exhaust steam pressure $8.5 \mathrm{kPa}$, twenty-four (24) stages (eight (8) high, six (6) intermediate and $10(5 \times 2)$ low pressure stages) and with three (3) low pressure heaters, two (2) high pressure heaters and one (1) de-aerator, which receives dry steam from the boiler and rotates a shaft coupled to the rotor of the generator to generate power; (iii) Condenser - surface type, cooling water is from lagoon water, No of passes -2 , condensing surface area - $10630 \mathrm{~m}^{2}$, No of tubes - 12142; (iv) Feed Water Pump pump after condenser and pump after deaerator; (v) FWH - one FWH for high pressure turbine, one feed water heater for intermediate pressure turbine and three feed water heater for low pressure turbine and (vi) Generator - is the radiant type, 3-phase, 2-pole, hydrogencooled, with output voltage of $16 \mathrm{kV}$, power of 245.8 MVA (221.22 MW), speed $3000 \mathrm{rpm}, 0.9$ power factor, exciting voltage of $440 \mathrm{~V}, 50 \mathrm{~Hz}$ frequency, armature current of $8870 \mathrm{~A}$ and field current of $2781 \mathrm{~A}$, ambient temperature of $45^{\circ} \mathrm{C}$, armature temperature rise of $55^{\circ} \mathrm{C}$, field temperature rise of $65^{\circ} \mathrm{C}$, and with natural circulation with single reheat and duct firing $[49,50]$. Tables 1 shows a summary of the operating parameters of the Egbin Thermal Power Plant.
Table 1

Summary of the Operating Parameter of Egbin Thermal Power Plant [49].

\begin{tabular}{ll}
\hline Components/Parameters & Values/Units \\
\hline Boiler & \\
Superheater outlet flow & $705 \mathrm{t} / \mathrm{h}$ \\
Superheater outlet steam pressure & $12.99 \mathrm{MPa}$ \\
Superheater outlet steam temperature & $541{ }^{\circ} \mathrm{C}$ \\
Reheater outlet steam temperature & $541{ }^{\circ} \mathrm{C}$ \\
Feedwater temperature, natural gas firing & $204{ }^{\circ} \mathrm{C}$ \\
Oil firing & $202.8^{\circ} \mathrm{C}$ \\
Turbine & \\
Maximum continuous rating & $220000 \mathrm{~kW}$ \\
Turbine speed & $3000 \mathrm{RPM}$ \\
Initial steam pressure & $12.5 \mathrm{MPa}$ \\
Initial steam temperature & $538^{\circ} \mathrm{C}$ \\
Reheat steam temperature & $538^{\circ} \mathrm{C}$ \\
Exhaust steam pressure & $8.5 \mathrm{kPa}$ \\
Generator & \\
Type & $\mathrm{TCDF} 26$ \\
Output & $245,800 \mathrm{kVA} / 221220 \mathrm{~kW}$ \\
Power factor & 0.9 \\
Pole & 2 \\
Frequency & $50 \mathrm{~Hz}$ \\
Exciting voltage & $440 \mathrm{~V}$ \\
Voltage & $16 \mathrm{kV}$ \\
Phase & $3 \mathrm{AC}$ power \\
\hline
\end{tabular}

\subsection{Thermodynamic analysis}

The operation of the steam power plant is considered in the steadystate condition. The pressure loss throughout the pipelines is assumed negligible. Applying the steady flow energy equation to each of the processes based on a unit mass of fluid, and neglecting changes in kinetic and potential energy, the work and heat quantities are evaluated in terms of the properties of the fluid. Energy analysis of each component is given as follow:

Mass balance is given by [51]:

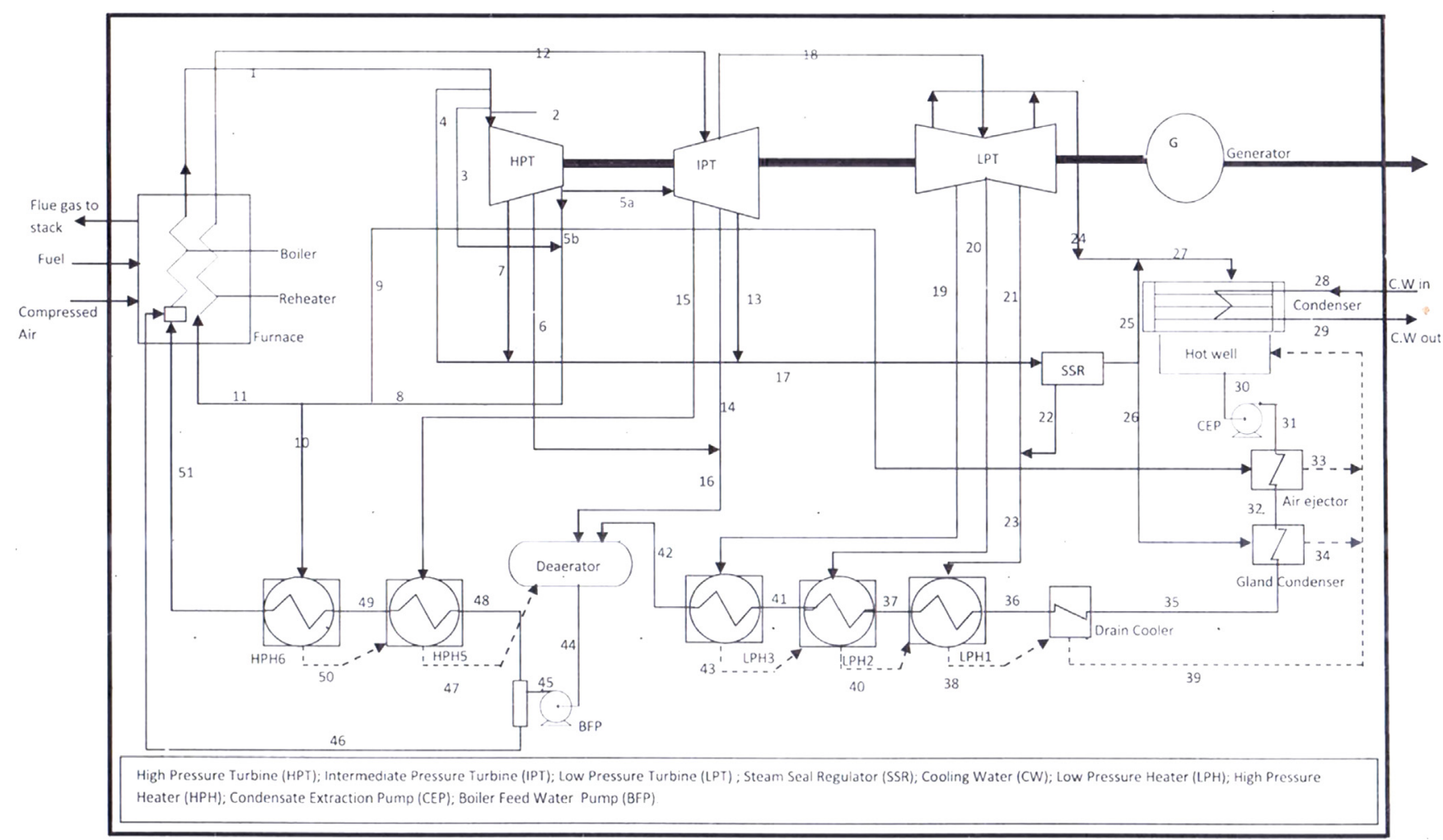

Fig. 1. Egbin Power Plant Process Flow Diagram Ref. [49] 
$\sum \dot{m}_{\text {in }}=\sum \dot{m}_{\text {out }}$

where, $\dot{m}_{\text {in }}$ and $\dot{m}_{\text {out }}$ are mass flow rates into and out of the system, respectively.

Energy balance is given as [51]:

$\sum_{\text {in }} \dot{E}_{\text {in }}+Q=\sum_{\text {Out }} \dot{E}_{\text {out }}+\dot{W}$

where, $\dot{E}_{\text {in }}$ and $\dot{E}_{\text {out }}$ are energy rate into and out of the system, respectively, $Q$ and $W$ are heat and work transferred into and out of the system, respectively.

All the analyses presented below are based on the notations in Fig. 1.

\subsubsection{Energy analysis of turbine}

The total work output from the low, intermediate and high pressure steam turbines is given by [52]:

$W_{T}$

$$
\begin{aligned}
= & \left(h_{1}-h_{5 b}\right)+\left(1-m_{s 1}\right)\left(h_{5 b}-h_{11}\right)+\left(1-m_{s 1}\right) \\
& \left(h_{12}-h_{15}\right)+\left(1-m_{s 1}-m_{s 2}\right)\left(h_{15}-h_{16}\right) \\
& +\left(1-m_{s 1}-m_{s 2}-m_{s 3}\right)\left(h_{16}-h_{19}\right)+\left(1-m_{s 1}-m_{s 2}-m_{s 3}-m_{s 4}\right) \\
& \left(h_{19}-h_{20}\right)+\left(1-m_{s 1}-m_{s 2}-m_{s 3}-m_{s 4}-m_{s 5}\right)\left(h_{20}-h_{21}\right)+ \\
& \left(1-m_{s 1}-m_{s 2}-m_{s 3}-m_{s 4}-m_{s 5}-m_{s 6}\right)\left(h_{21}-h_{24}\right)(k J / k g)
\end{aligned}
$$

where, $m_{s 1}, m_{s 2}, m_{s 3}, m_{s 4}, m_{s 5}, m_{s 6}$ are mass of steam extracted at HPT, IPT and LPT to preheat feedwater at HPH6, HPH5, Daerator, LPH3, LPH2 and LPH1, respectively. These are calculated as follows [53]:

$m_{s 1}=\frac{h_{51}-h_{49}}{h_{10}-h_{50}}(\mathrm{~kg})$

$m_{s 2}=\frac{h_{49}-h_{48}}{h_{15}-h_{47}}(\mathrm{~kg})$

$m_{s 3}=\frac{\left(1-m_{s 1}-m_{s 2}\right) h_{42}}{h_{16}-h_{44}}(\mathrm{~kg})$

$m_{s 4}=\frac{\left(1-m_{s 1}-m_{s 2}-m_{s 3}\right)\left(h_{41}-h_{42}\right)}{h_{19}-h_{43}}(\mathrm{~kg})$

$m_{s 5}=\frac{\left(1-m_{s 1}-m_{s 2}-m_{s 3}-m_{s 4}\right)\left(h_{42}-h_{32}\right)}{h_{20}-h_{40}}(\mathrm{~kg})$

$m_{s 6}=\frac{\left(1-m_{s 1}-m_{s 2}-m_{s 3}-m_{s 4}-m_{s 5}\right)\left(h_{37}-h_{36}\right)}{h_{23}-h_{38}}(\mathrm{~kg})$

\subsubsection{Energy analysis of pumps}

The total pumping work by condensate extraction pump (CEP) and boiler feedwater pump (BFP) is given as [53]:

$W_{P}$

$$
\begin{aligned}
= & \left(1-m_{s 1}-m_{s 2}\right)\left(h_{45}-h_{44}\right)+ \\
& \left(1-m_{s 1}-m_{s 2}-m_{s 3}-m_{s 4}-m_{s 5}-m_{s 6}\right)\left(h_{31}-h_{32}\right)(\mathrm{kJ} / \mathrm{kg})
\end{aligned}
$$

where, $m_{s 1}, m_{s 2}, m_{s 3}, m_{s 4}, m_{s 5}$, and $m_{s 6}$ are as defined in Eqs. (4)-(9); $h_{i}$ are enthalpies of the working fluid at designated states.

\subsubsection{Network output of plant}

The network output of steam power plant is given by [44]:

$w_{N}=w_{T}-w_{P}\left(\frac{k J}{k g}\right)$

Power output is given as [39]:

$P=\frac{W_{N} \times 300 \times 10^{3}}{3600}(M W)$
2.2.3.1. Correction factor of power output. Correction factor of power output is given by [54]:

$P_{c f}=P_{d} / P$

where, $P_{d}$ is the designed power and $P$ is the calculated power output from Eq. (12).

\subsubsection{Energy analysis of heat rejection from condenser}

Heat rejection from condenser is given by [51]:

$Q_{R C}=\left(1-m_{s 1}-m_{s 2}-m_{s 3}-m_{s 4}-m_{s 5}-m_{s 6}\right)\left(h_{27}-h_{30}\right)\left(\frac{\mathrm{kJ}}{\mathrm{kg}}\right)$

\subsubsection{Energy analysis of boiler and reheater}

The power plant under consideration consists of the steam generator, which is the combination of the boiler and reheater. In this work, we considered related operating parameters such as temperature, pressure, enthalpy and mass flow rate of the working fluid to assess heat transferred from the boiler and reheater.

The total heat transferred to feedwater in the boiler, and reheater can be calculated by using the energy balance as follows [52]:

$Q_{T}=\left(h_{1}-h_{51}\right)+\left(1-m_{s 1}\right)\left(h_{12}-h_{11}\right)\left(\frac{k J}{k g}\right)$

where, $m_{i}$ and $h_{i}$ are mass and enthalpy of the working fluid at the designated states, $m_{s 1}$ is as defined in Eq. (4)

2.2.6. Thermal efficiency and other plant performance indices

The thermal efficiency of the plant is given as $[47,53]$ :

$\eta_{t h}=\frac{W_{N}}{Q_{T}}$

2.2.6.1. Boiler efficiency. The boiler efficiency is defined as the heat supplied to the steam in the boiler expressed as a percentage of the chemical energy of the fuel which is available on combustion. Mathematically, boiler efficiency is given as [47]:

$\eta_{B}=\frac{\dot{m}_{s}\left(h_{1}-h_{51)}\right.}{m_{f} X L H V}$

where, $\dot{m}_{s}$ is steam generation rate in the boiler in $\mathrm{kg} / \mathrm{s}, \mathrm{h}_{1}$ and $\mathrm{h}_{51}$ are enthalpies of steam at inlet to high pressure turbine (HPT) and feedwater into the boiler, respectively; $m_{f}$ and $L H V$ are the mass flow rate $(\mathrm{kg} / \mathrm{s})$ and lower heating value $(47141 \mathrm{~kJ} / \mathrm{kg})$ of the fuel (Natural Gas) for combustion in the boiler.

2.2.6.2. Specific steam consumption (SSC). SSC is the steam flow required to develop unit power output in a steam power plant. Mathematically, it is given as [53]:

$\mathrm{SSC}=\frac{3600}{w_{N}}\left(\frac{\mathrm{kg}}{k W h}\right)$

2.2.6.3. Specific fuel consumption (SFC). Specific fuel consumption $(S F C)$ is one of the most important metrics employed in the power plant. It indicates how efficiently a power plant converts chemical into mechanical energy. Mathematically, it is expressed as follows [51]:

$S F C=\frac{\left\{\dot{m}_{s}\left(h_{1}-h_{51}\right\}\right.}{\left(\eta_{B} x L H V\right)}\left(\frac{k g}{s}\right)$

where SFC is specific fuel consumption; $\dot{m}_{s}$ is steam generation rate in $\mathrm{kg} / \mathrm{s} ; h_{1}$ is the enthalpy of steam at turbine inlet; $h_{51}$ is the enthalpy of feedwater at the boiler inlet; $\eta_{B}$ is boiler efficiency, and LHV is Lower heating value of fuel $(47,141 \mathrm{~kJ} / \mathrm{kg})$.

2.2.6.4. Heat rate. Heat rate in the steam power plant is given by [47]: 
Heat rate $=\frac{3600}{\eta_{t h}} k J / k W h$

\subsubsection{Other plant parameters}

2.2.6.5.1. Total enthalpy rise of feedwater in regenerative cycle. The total enthalpy rise of feed water for $n$ heaters by regenerative feedwater heating is given by [47]:

$\Delta h_{t}=\frac{n}{n+1}\left(h_{S}-h_{c}\right)\left(\frac{k J}{k g}\right)$

where $\Delta \mathrm{h}_{\mathrm{t}}$ is the total enthalpy rise of feed water for $n$ heaters by regenerative feedwater beating, $n$ is the number of feedwater heaters, $h_{s}$ is the saturated steam enthalpy, and $h_{c}$ is the condensate (saturated liquid leaving condenser) enthalpy.

2.2.6.5.2. Total temperature rise of feedwater. The total temperature rises of feedwater, $\Delta \mathrm{t}_{\mathrm{fw}}$ due to regeneration for the maximum cycle efficiency is given by [52]:

$\Delta t_{f w}=\frac{n}{n+1} \Delta t_{B S C}\left({ }^{\circ} \mathrm{C}\right)$

where, $\Delta \mathrm{t}_{\mathrm{BSC}}=$ Boiler saturation temperature - Condenser temperature

\subsection{Thermodynamic performance analysis of power plant using cycle pad}

In this study, performance analysis of a reheat - regenerative steam power plant was carried out using cycle pad. Rankine cycle was modified using CyclePad, and the effects of regeneration on the cycle's thermal efficiency, specific fuel consumption, boiler efficiency, specific steam consumption and condenser loss were examined.

Analysis of thermodynamic cycle is complicated, tedious and timeconsuming. The analysis would be more meaningful, time-saving, and fun using computer software such as CyclePad as a tool to help in the cycle analysis, design and optimization. It would be easier to manipulate any parameters in the cycle and see its effect on the performance indices of the cycle.

CyclePad is being considered in this work due to its unique features: Has potential to handle routine calculations and facilitates sensitivity analyses. It has capability to keep track of modelling assumptions and their consequences. Finally, it easily detects physically impossible designs, using a combination of qualitative constraints and numerical reasoning. Besides these, CyclePad's interface assists the user to design by providing straightforward critiques of the structure. Once the structural description of the cycle is finished, CyclePad allows the user to enter an analysis mode. In analysis mode, the particular properties of the system, such as the choice of the working fluid, the values of specific numerical parameters, and modelling assumptions can be entered and explored. The value that CyclePad brings to its users is a reduction in time while moving from concept to finished design. This time saving allows the user to move to his physical prototyping stage faster, thereby eliminating individual prototyping costs and improving cycle design more rapidly. Fig. 2 shows a schematic diagram of the reheat- regenerative Rankine cycle [55].

\section{Results and discussion}

The thermodynamic properties of steam, including pressure, temperature, enthalpy, entropy, specific volume and mass flow rates at state points of reheat - regenerative cycle (Fig. 1) were calculated using cyclepad V2.0. Results of the analysis for Rankine cycle without FWH, with $1,2,3$, and 4 FWHs are presented in chronological order in this section. Fig. 3 shows the layout of the reheat - regenerative cycle with 4-FWHs generated using cyclepad as a sample.

Analysis of reheat - regenerative cycle without FWH shows that states S1 to S7 are the conditions of the working fluid at the inlet to HPT, reheater, IPT, LPT, condenser, boiler feedwater pump and boiler, respectively. Assuming steady-state condition and because there is no steam extracted, the mass flow rate of steam is the same $(110.6 \mathrm{~kg} / \mathrm{s})$ through the cycle. The highest temperature in the cycle is $545^{\circ} \mathrm{C}$ at the inlet to HPT while the least temperature is $42.67{ }^{\circ} \mathrm{C}$ at the inlet to condenser and feedwater pump.

Analysis of the thermodynamic parameters of reheat - regenerative cycle with $1-$ FWH shows that states S1 to S11 are the conditions of the working fluid at the inlet to HPT, reheater, IPT, steam extraction point, LPT, condenser, condensate extraction pump, FWH, boiler feedwater pump and boiler, respectively. With 1- FWH, there is one point of extraction of steam, that is at S9. The mass flow rate of steam extracted is $1.76 \mathrm{~kg} / \mathrm{s}$. The temperature at the inlet to the boiler is $55.56{ }^{\circ} \mathrm{C}$ at $\mathrm{S} 11$. As expected, the mass flow rate of the working fluid through the cycle is not uniform due to the extraction of steam to pre-heat the feedwater in the closed FWH.

Reheat - regenerative cycle with 2- FWHs implies the extraction of steam occurs at two locations. States S1 to S15 are the conditions of the working fluid at the inlet to HPT, first steam extraction point, reheater, IPT, second steam extraction point, LPT, condenser, condensate extraction pump, FWH2, feedwater pump, FWH1, boiler feedwater and boiler, respectively. Mass flow rates of extracted steam at points S10 and $S 11$ are $10.01 \mathrm{~kg} / \mathrm{s}$ and $1.76 \mathrm{~kg} / \mathrm{s}$, respectively. The temperature and enthalpy at the inlet to the boiler (S15) increased to $126^{\circ} \mathrm{C}$ and $538 \mathrm{~kJ} / \mathrm{kg}$, respectively compared to the cycle with 1 - FWH.

Thermodynamic analysis of reheat- regenerative cycle with 3- FWHs

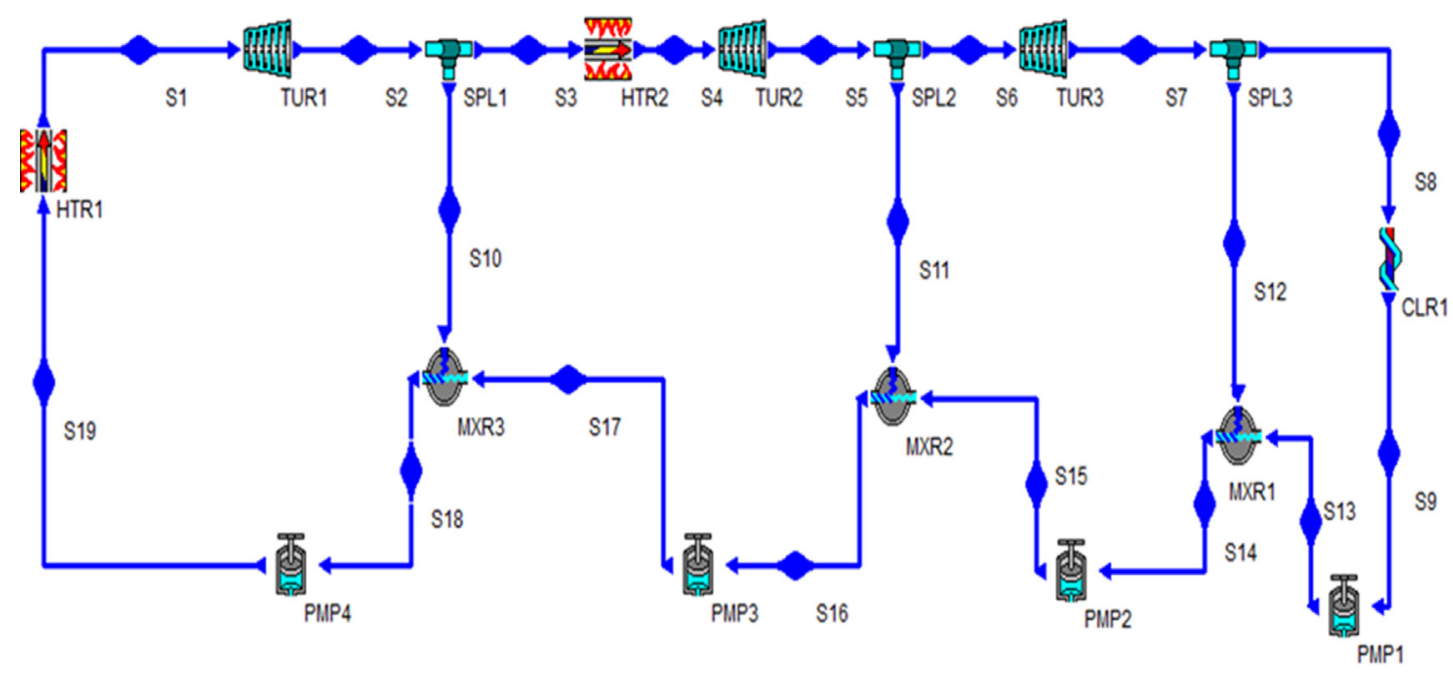

Fig. 2. A schematic Diagram of Reheat - Regenerative Rankine Cycle on CyclePad. 


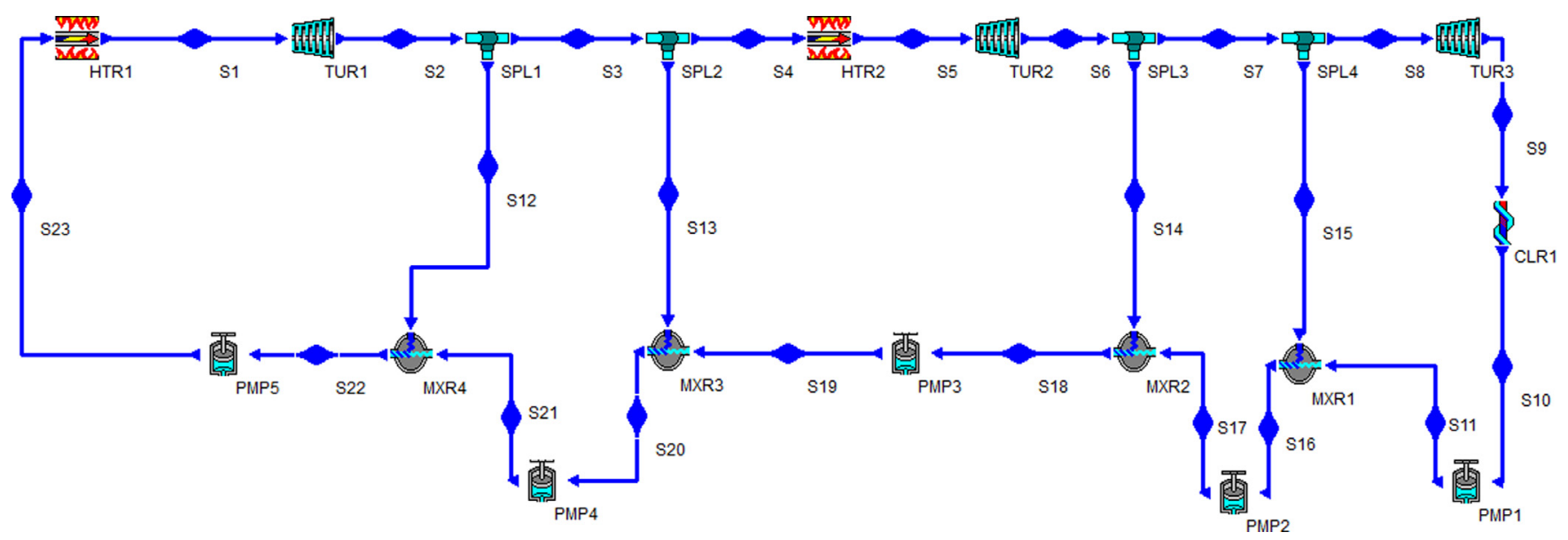

Fig. 3. A Layout of Reheat - Regenerative Cycle with 4-FWHs as Generated Using Cyclepad.

Table 2

Comparison of performance parameters with various number of FWHs.

\begin{tabular}{|c|c|c|c|c|c|c|c|c|c|}
\hline $\begin{array}{l}\text { No.of feed- } \\
\text { water } \\
\text { heaters }\end{array}$ & $\begin{array}{l}\text { Thermal } \\
\text { Efficiency (\%) }\end{array}$ & $\begin{array}{l}\text { Network } \\
\text { Output (MW) }\end{array}$ & $\begin{array}{l}\text { Heat rate } \\
(\mathrm{kJ} / \mathrm{kWh})\end{array}$ & $\begin{array}{l}\text { Back work } \\
\text { ratio }(\%)\end{array}$ & $\begin{array}{l}\text { Specific steam } \\
\text { consumption (kg/ } \\
\text { kWh) }\end{array}$ & $\begin{array}{l}\text { Boiler } \\
\text { Efficiency (\%) }\end{array}$ & $\begin{array}{l}\text { Fuel consumption } \\
(\mathrm{kg} / \mathrm{s})\end{array}$ & $\begin{array}{l}\text { Heat rejected in } \\
\text { Condenser }(\mathrm{kJ} / \mathrm{kg})\end{array}$ & $\begin{array}{l}\text { Heat input to } \\
\text { the cycle }(\mathrm{kJ} / \\
\mathrm{kg})\end{array}$ \\
\hline 0 & 42.17 & 152.22 & 8536.87 & 93.9 & 0.0234 & 79.0 & 9.697 & 209.32 & 361.11 \\
\hline 1 & 43.07 & 150.24 & 8534.85 & 94.0 & 0.0240 & 84.0 & 8.975 & 205.99 & 355.38 \\
\hline 2 & 43.87 & 136.59 & 8530.81 & 95.0 & 0.0263 & 87.0 & 7.872 & 187.04 & 322.82 \\
\hline 3 & 44.47 & 120.91 & 8522.73 & 95.0 & 0.0298 & 91.0 & 6.657 & 165.23 & 285.47 \\
\hline 4 & 44.97 & 104.28 & 8492.57 & 97.0 & 0.0345 & 94.0 & 5.548 & 142.30 & 245.90 \\
\hline 5 & 45.37 & 104.15 & 8491.07 & 97.4 & 0.0397 & 94.6 & 5.530 & 140.50 & 244.60 \\
\hline 6 & 45.57 & 103.98 & 8489.17 & 97.7 & 0.0461 & 95.2 & 5.215 & 139.80 & 242.65 \\
\hline 7 & 45.67 & 103.86 & 8398.07 & 97.9 & 0.0536 & 95.6 & 4.851 & 138.70 & 241.35 \\
\hline 8 & 45.77 & 103.45 & 8390.67 & 98.0 & 0.0625 & 95.8 & 4.716 & 137.89 & 240.95 \\
\hline 9 & 45.87 & 103.25 & 8368.17 & 98.2 & 0.0730 & 96.0 & 4.706 & 130.96 & 239.87 \\
\hline 10 & 45.97 & 102.89 & 8318.48 & 98.6 & 0.0854 & 96.4 & 4.686 & 129.68 & 237.98 \\
\hline
\end{tabular}

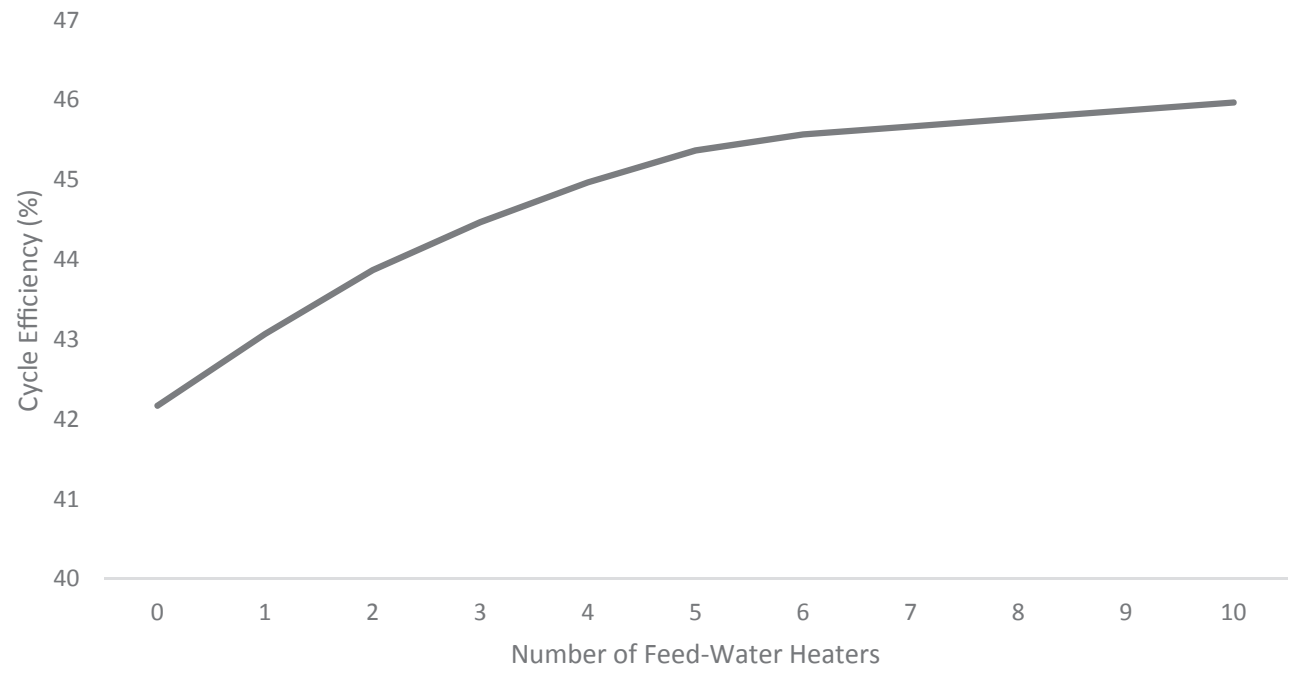

Fig. 4. Plot of Cycle Efficiency against Number of closed FWHs.

shows that states S1 to S19 are the conditions of the steam at the inlet to HPT, first steam extraction point, reheater, IPT, second steam extraction point, third steam extraction point, LPT, condenser, condensate extraction pump, FWH3, feedwater pump, FWH2, feedwater pump, FWH1 and boiler, respectively. Mass flow rates of extracted steam at points at S10, S11 and S12, are $16.22 \mathrm{~kg} / \mathrm{s}, 1.89 \mathrm{~kg} / \mathrm{s}$ and $5.11 \mathrm{~kg} / \mathrm{s}$, respectively. The temperature and enthalpy at the inlet to the boiler (S19) increased to $204{ }^{\circ} \mathrm{C}$ and $875 \mathrm{~kJ} / \mathrm{kg}$ due to an increase in the number of FWHs to three.
Analysis of state thermodynamic properties of reheat - regenerative cycle with 4 - FWHs (Fig. 3) states S1 to S23 are the conditions of the steam at the inlet to HPT, first steam extraction point, second steam extraction point, reheater, IPT, third steam extraction point, fourth steam extraction point, LPT, condenser, condensate extraction pump, FWH4, feedwater pump, FWH3, feedwater pump, FWH2, feedwater pump, FWH1, feedwater pump and boiler, respectively. The mass flow rates of steam extracted from the points S12, S13, S14 and S15 are $15.01 \mathrm{~kg} / \mathrm{s}, 11.12 \mathrm{~kg} / \mathrm{s}, 5.32 \mathrm{~kg} / \mathrm{s}$ and $3.97 \mathrm{~kg} / \mathrm{s}$, respectively. The inlet 
Table 3

Total Enthalpy Rise and Total Temperature Rise of Feedwater in Regeneration Cycle.

\begin{tabular}{|c|c|c|}
\hline No. of Heaters & Temperature Rise $\left(\Delta \boldsymbol{t}_{\boldsymbol{f} w}\right)\left({ }^{\circ} \mathrm{C}\right)$ & Enthalpy Rise $\left(\Delta \boldsymbol{h}_{\boldsymbol{t}}\right)(\mathrm{kJ} / \mathrm{kg})$ \\
\hline 0 & 0.00 & 0.00 \\
\hline 1 & 247.67 & 1639.15 \\
\hline 2 & 330.22 & 2185.53 \\
\hline 3 & 371.50 & 2458.73 \\
\hline 4 & 396.26 & 2622.64 \\
\hline 5 & 412.78 & 2731.92 \\
\hline 6 & 424.57 & 2809.97 \\
\hline 7 & 433.41 & 2868.51 \\
\hline 8 & 440.29 & 2914.04 \\
\hline 9 & 445.80 & 2950.47 \\
\hline 10 & 450.30 & 2980.27 \\
\hline
\end{tabular}

temperature and enthalpy to the boiler (S23) are $280.1{ }^{\circ} \mathrm{C}$ and $1233 \mathrm{~kJ} /$ $\mathrm{kg}$, respectively.

To assess the optimal performance of FWH, the number of FWHs was increased from 5 to 10 , and the performance parameters are presented in Table 2. Table 2 compares the computed performance parameters (using CyclePad) for the power cycle without FWH and with one to ten FWHs.

From the above performance parameters, the highest thermal efficiency of the actual steam power cycle is $45.37 \%$ when working with five FWHs (excluding deaerator). That is the exact number of heaters in the existing selected steam power plant. The steam power cycle, when simulated by increasing the number of heaters to ten, the cycle efficiency, increased to $45.97 \%$. But the efficiency gain $(\Delta \eta)$ successively diminishes with an increase in the number of heaters (Fig. 4). From Fig. 4, a significant gain in cycle efficiency occurred between first and sixth heater. Hence, increasing the closed FWHs above six might not give a substantial gain in a cycle of efficiency of the selected plant. Five to seven points of extraction are often used in practice.

From Table 2, the network output decreases from 152.22 MW to 102.89 MW. On the contrary, specific steam consumption increases from $0.0234 \mathrm{~kg} / \mathrm{kWh}$ to $0.0370 \mathrm{~kg} / \mathrm{kWh}$. When the plant operates with $1,2,3,4$ and 5 heaters increase in SSC is approximately $2.5 \%, 8.8 \%$, $11.8 \%, 13.6 \%$ and $15.07 \%$, respectively. However, when compared to the regeneration with 6 to 10 heaters, SSC increased from $16.12 \%$ to $16.98 \%$. This result shows that the regeneration steam consumption increases for power generation because it decreases the useful network output and increases the steam flow.

Considering the specific fuel consumption, SFC decreases significantly with an increase in the number of closed FWHs. When the plant operates with five heaters, SFC varies from $8.975 \mathrm{~kg} / \mathrm{s}$ to $5.530 \mathrm{~kg} / \mathrm{s}$. The SFC further decreased when the plant was simulated using 6 to $10 \mathrm{FWHs}$, and the value ranges from $5.215 \mathrm{~kg} / \mathrm{s}$ to $4.686 \mathrm{~kg}$ / $\mathrm{s}$. This variation is more important than the previous parameter (SSC) because water is less expensive than the fuel burnt. As regard heat rejected in condenser and heat input to the cycle, these two parameters decrease with an increase in the number of surface FWHs. Heat rejected in condenser and heat input in the cycle drops from $205.99 \mathrm{~kJ} / \mathrm{kg}$ to $129.68 \mathrm{~kJ} / \mathrm{kg}$, and $355.38 \mathrm{~kJ} / \mathrm{kg}$ to $237.98 \mathrm{~kJ} / \mathrm{kg}$ for the 10 closed FWHs.

With an increase in the number of FWHs, the thermal efficiency of the plant increased by $8.3 \%$. As the cycle thermal efficiency increases, the heat rate decreases from $8536.87 \mathrm{~kJ} / \mathrm{kWh}$ to $8318.48 \mathrm{~kJ} / \mathrm{kWh}$. Moreover, fuel consumption decreases by $51.7 \%$, but the specific steam consumption increased by $72.5 \%$ with an increase in the number of FWHs. Improving the power plant efficiency by increasing the number of FWHs could alleviate the negative effect of fuel consumption on $\mathrm{CO}_{2}$ emission.

The correction factor of power output as computed using equation (15) increases from 1.45 to 2.14 as FWHs risen from 0 to 10 and power output decreases from 152.22 MW to 102.89 MW. This results from the fact that as the number of FWHs increases, the power output falls due to increasing in extracted quantity of bled steam.

\subsection{Total enthalpy rise and total temperature rise of feedwater in regeneration cycle}

The total enthalpy rise and total temperature rise of FWH in the reheat - regenerative cycle are computed from Eqs. (21) and (22). Table 3 shows the total enthalpy rise and total temperature rise for the cycle without FWH and cycle with 1 to 10 closed FWHs. From Table 3, both enthalpy rise and temperature rise increase with an increase in the number of closed FWHs. As the number of heaters increases, so is the total temperature rise of feed water $\left(\Delta t_{f w}\right)$, by regeneration, less becomes the heat added to water in the boiler, more becomes the mean temperature of heat addition, and more is the cycle efficiency.

The cycle thermal efficiency is a function of FWH temperature. Hence, the efficiency gain experience drops with an increase in the number of heaters. That is, the law of diminishing return set in. From this study, the highest increment in thermal efficiency was obtained with the first heater. The increases for each additional heater after that successively diminish in the following order: $82.55{ }^{\circ} \mathrm{C}, 41.28{ }^{\circ} \mathrm{C}$ and $24.76{ }^{\circ} \mathrm{C}$ for heaters 2,3 and 4 respectively. By increasing the heaters from 5 to 10 , gain in feed water temperature diminishes as $16.52{ }^{\circ} \mathrm{C}$, $11.79{ }^{\circ} \mathrm{C}, 8.84{ }^{\circ} \mathrm{C}, 6.9{ }^{\circ} \mathrm{C}, 5.5{ }^{\circ} \mathrm{C}$ and $4.5{ }^{\circ} \mathrm{C}$ for $5,6,7,8,9$ and 10 heaters respectively.

\section{Conclusion}

In this study, Rankine cycle was modified using CyclePad, and the effects of regeneration on steam power plant's performance indices were examined. Results of the study show that increase in the number of FWHs from 1 to 10, the thermal efficiency of the plant increased by $8.3 \%$. As the thermal efficiency increases, the heat rate decreases from $8536.87 \mathrm{~kJ} / \mathrm{kWh}$ to $8318.48 \mathrm{~kJ} / \mathrm{kWh}$, the fuel consumption decreases by $51.7 \%$ but the specific steam consumption increased by $72.5 \%$ with an increase in the number of FWHs. From the results of this study, it can be concluded that an increase in the number of FWHs decreases the fuel consumption, heat rate, heat rejected in condenser and heat input to the cycle. This effect invariably can lead to a reduction in operating cost and environmental impact.

\section{Declaration of Competing Interest}

The authors declare that they have no known competing financial interests or personal relationships that could have appeared to influence the work reported in this paper.

\section{Acknowledgement}

The authors acknowledge Management of Covenant University through CUCRID for continued publication support.

\section{References}

[1] Deheri C, Acharya SK, Thatoi DN, Mohanty AP. A review on performance of biogas and hydrogen on diesel engine in dual fuel mode. Fuel 2020;260:116337.

[2] Shi Y, Liu Q, Shao Y, Zhong W. Energy and exergy analysis of oxy-fuel combustion based on circulating fluidized bed power plant firing coal, lignite and biomass. Fuel 2020;269(117424):1-12.

[3] Ozdil NFT, Tantekin A, Erbay Z. energy and exergy analyses of a fluidized bed coal combustor steam plant in textile industry. Fuel 2016;183:441-8.

[4] Liu X, Chen J, Luo X, Wang M, Meng H. Study on heat integration of supercritical coal-fired power plant with post-combustion $\mathrm{CO} 2$ capture process through process simulation. Fuel 2015;158:625-33.

[5] Ozdemir E, Kilic M. Thermodynamic analysis of basic and regenerative organic rankine cycles using dry fluids from waste heat recovery. J Thermal Eng 2018;4(5):2381-93.

[6] Mohammadi A, Ahmadi MH, Bidi M, Ghazvini M, Ming T. Exergy and economic analyses of replacing feedwater heaters in a Rankine cycle with parabolic trough 
collectors. Energy Rep 2018;4:243-51.

[7] Manigandan S, Sarweswaran R, Booma Devi P, Sohret Y, Kondratiev A, Venkatesh S, Rakesh Vimal M, Jensin Joshua J. Comparative study of nanoadditives TiO2, CNT, $\mathrm{Al} 2 \mathrm{O} 3, \mathrm{CuO}$ and $\mathrm{CeO} 2$ on reduction of diesel engine emission operating on hydrogen fuel blends. Fuel 2020;262:116336. https://doi.org/10.1016/j.fuel.2019. 116336.

[8] Manigandan S, Ponnusamy VK, Booma Devi P, Oke SA, Sohret Y, Venkatesh SR, et al. Effect of nanoparticles and hydrogen on combustion performance and exhaust emission of corn blended biodiesel in compression ignition engine with advanced timing. Int J Hydrogen Energy 2020;45:3327-39.

[9] Huang D, Zhou H, Lin L. Biodiesel: An Alternative to Conventional Fuel, International Conference on Future Energy, Environment, and Materials. Energy Procedia 2012;16:1874-85.

[10] Abed KA, Gad MS, El Morsi AK, Sayed MM, Abu Elyazeed S. Effect of biodiesel fuels on diesel engine emissions. Egypt J Pet 2019;28:183-8.

[11] Yusri IM, Mamat R, Akasyah MK, Jamlos MF, Yusop AF. Evaluation of engine combustion and exhaust emissions characteristics using diesel/butanol blended fuel. Appl Therm Eng 2019;156:209-19. https://doi.org/10.1016/j. applthermaleng.2019.02.028.

[12] Kumar R. A critical review on energy, exergy, exergoeconomic and economic (4-E) analysis of thermal power plants. Eng Sci Technol, Int J 2017;20:283-92.

[13] Eke, M.N, Onyejekwe, D.C, Iloeje, O.C, Ezekwe, C.I and Akpan, P.U(2018), Energy and Exergy Evaluation of a 220MW Thermal Power Plant, Nigerian Journal of Technology Vol. 37, No. 1, pp. 115 - 123.

[14] Mohammadi K, McGowan JG. Thermodynamic analysis of hybrid cycles based on a regenerative steam Rankine cycle for cogeneration and trigeneration. Energy Convers Manage 2018;158:460-75. https://doi.org/10.1016/j.enconman.2017.12. 080.

[15] Rocca AL, Ferrante A, Haffner-Staton E, Cairns A, Weilhard A, Sans V, et al. Investigating the impact of copper leaching on combustion characteristics and particulate emissions in HPCR diesel engines. Fuel 2020;263:116719.

[16] Lee Z, Kim T, Park S, Park S. Review on spray, combustion, and emission characteristics of recent developed direct-injection spark ignition (DISI) engine system with multihole type injector. Fuel 2020;259:116209.

[17] Ryzhkov A, Bogatova T, Gordeev S. Technological solutions for an advanced IGCC plant. Fuel 2018;214:63-72.

[18] Zhou J, LingSu, S, Xu, J, Xu, K, Wang, Y, Hu, S, Zhu, M and Xiang, J, P. Exergy analysis of a 1000MW single reheat advanced supercritical carbon dioxide coalfired partial flow power plant. Fuel 2019;255(115777):1-10.

[19] Esen AN, Duzgit Z, Toy AO, Günay ME. An Overview of Energy Technologies for a Sustainable Future. Springer International Publishing Switzerland; 2015. p. 1-18.

[20] Aleme HG, Barbeira PJS. Determination of flash point and cetane index in diesel using distillation curves and multivariate calibration. Fuel 2012;102:129-34.

[21] Rashidi MM, Aghagoli A, Ali M. 'Thermodynamic Analysis of a Steam Power Plant with Double Reheat and Feed Water Heaters', Advances in Mechanical Engineering Volume 2014. Article ID 2014;940818:1-11. https://doi.org/10.1155/2014/ 940818.

[22] Ameri M, Ahmadi P, Hamidi A. Energy, exergy and exergoeconomic analysis of a steam power plant: a case study. Int J Energy Res 2009;33(5):499-512.

[23] Raju SN, Babu HN, Kumar PD. Analysis of Regenerative System in Steam Power Plant. Int J Eng Appl Sci (IJEAS) 2015;2(7):39-44.

[24] Pandey, M and Gogoi, T.K (2013), 'Energy and Exergy Analysis of A Reheat Regenerative Vapor Power Cycle', International Journal of Emerging Technology and Advanced Engineering Volume 3, Special Issue 3: ICERTSD 2013, pages 427 434.

[25] Padilla, R.V, Archibold, A.R, Demirkay, G, Besarati, S, Goswami, D.Y, Rahman, M.M , Elias L. and Stefanakos, E.L (2011), 'Performance Analysis af a Rankine-Goswami Combined Cycle', Proceedings of the ASME 2011 5th International Conference on Energy Sustainability ES2011, August 7-10, 2011, Washington, DC, USA, pp. 1 - 9.

[26] Akolekara, H.D, Srinivasan, P and Challa, J.S (2014), 'Development of a Simulation Program to Optimize Process Parameters of Steam Power Cycles', Int. J. of Thermal \& Environmental Engineering Volume 8, No. 1 (2014) 55-61.

[27] Srinivas T, Gupta AV, Reddy BV. Generalized Thermodynamic Analysis of Steam Power Cycles with ' $n$ ' Number of Feedwater Heaters. Int J Thermodynamics 2007;10(4):177-85.

[28] Toledo M, Abugaber J, Lugo R, Salazar M, Rodríguez A, Rueda A. Energetic analysis of two thermal power plants with six and seven heaters. Open J Appl Sci 2014;4:6-12. https://doi.org/10.4236/ojapps.2014.41002.

[29] Walter AH. Essergy Optimization of Regenerative Feedwater Heaters, M.Sc Thesis. Georgia Institute of Technology; 1978.
[30] Wijaya AA, Widodo BUK. The Effect of Feedwater Heaters Operation Schemes to a 200 MW Steam Power Plant Heat Rate Using Cycle-Tempo Software, IPTEK. J Eng 2018;4(3):33-7.

[31] Kumar BM, Sravanthi B. Roll of Feedwater Heaters in 120 MW Thermal Power Plant. Int J Eng Res Dev 2018;14(1):67-73.

[32] Almedilla JR, Pabilona LL, Villanueva EP. Performance Evaluation and Off Design Analysis of the HP and LP Feed Water Heaters on a $3 \times 135$ MW Coal Fired Power Plant. J Appl Mech Eng 2018;7(3):1-14.

[33] Kushwaha KC, Koshti B. Performance Analysis and off Design Behaviour of FeedWater Heater. Int J Res Aeronautical Mech Eng 2015;3(10):9-15.

[34] Shabani GAS, Ameri M, Akbari O, Seifi A. Performance assessment and leakage analysis of feed water pre-heaters in natural gas-fired steam power plants. J Power Technol 2018;98(4):352-64.

[35] Almedilla JR, Pabilona LL, Villanueva EP. Feed Water Heaters Performance Indicators and Characteristics on the 405MW Coal-Thermal Power Plant. Mindanao Journal of Science and Technology 2018;16:171-86.

[36] Álvarez-Fernández M, del Portillo-Valdés L, Alonso-Tristán C. Thermal analysis of closed feedwater heaters in nuclear power plants. Appl Therm Eng 2014;68:45-58.

[37] Gupta S, Tewari PC, Sharma AK. development of simulation model for performance evaluation of feedwater system in a typical thermal power plant. Journal of Industrial Engineering International 2011;7(12):1-9.

[38] Byregowda KC, Kumar SN, Reethi PK, Shivappa HA, Raju TN. Modeling and Simulation of Feed Water Heater for Steam Power Plant Systems. "International Journal of Ignited Minds" 2014;2(1):1-6.

[39] Devandiran E, Shaisundaram VS, Ganesh PS, Vivek S. Influence of Feed Water Heaters on the Performance of Coal Fired Power Plants. International Journal of Latest Technology in Engineering, Management \& Applied Science 2016;5(3):115-9.

[40] Dubey K.K and Mishra, R.S(2019), Energy-Exergy Analysis of Combined Reheating Regenerative Rankine Cycle using Entropy Generation Principle, International Journal of Recent Technology and Engineering Vol. 8(3), pp 3340 - 3344

[41] Elahifar S, Assareh E, Moltames R. Exergy analysis and thermodynamic optimization of a steam power plant based Rankine cycle system using intelligent optimization algorithms. Aust J Mech Eng 2019. https://doi.org/10.1080/14484846. 2019.1661807.

[42] Nsanzubuhoro CN, Bello-Ochende T, Malan AG. Second law analysis of a fossilgeothermal hybrid power plant with thermodynamic optimization of geothermal preheater. Heat Transfer. 2020;1-22. https://doi.org/10.1002/htj.21692.

[43] Vandani AMK, Joda F, Ahmadi F, Ahmadi MH. Exergoeconomic effect of adding a new feedwater heater to a steam power plant. Mechanics \& Industry 2017;18(224):1-13.

[44] Nag PK. Basic and Applied Thermodynamics. 8th Edition New Delhi, India: Tata McGraw-Hill Publishing Company Limited; 2006. p. 123-35.

[45] Cengel, Y.A and Boles, M.A (2015), Thermodynamics: An Engineering Approach (8th Edition), McGraw-Hill Education, 2 Penn Plaza, New York, NY, pp 335 - 345

[46] Gupta MK, Kaushik SC. Exergy analysis and investigation for various feed water heaters of direct steam generation solar-thermal power plant. Renewable Energy 2010;35:1228-35.

[47] Nag PK. Power Plant Engineering. New-Delhi, India: Tata McGraw-Hill Publishing Company Limited; 2008. p. 220-34.

[48] Oyedepo SO, Fagbenle RO. 'A Study of Implementation of Preventive Maintenance Programme in Nigeria Power Industry_Egbin Thermal Power Plant, Case Study. Energy and Power Eng 2011;3:207-20.

[49] Anozie AN, Odejobi OJ. The search for optimum condenser cooling water flow rate in a thermal power plant. Appl Therm Eng 2011;31:4083-90.

[50] Oyedepo SO. Energy and sustainable development in Nigeria: the way forward. Energy, Sustainability Soc 2012;2(15):1-17.

[51] Ameri M, Mokhtari H, Bahrami M. Energy, Exergy, Exergoeconomic and Environmental (4E) Optimization of a Large Steam Power Plant: A Case Study. Iran J Sci Technol Trans Mech Eng 2016;40:11-20.

[52] Rajput RK. Applied Thermodynamics. (2nd Edition), New Delhi: Laxmi Publications (P) LTD; 2014. p. 131-91.

[53] Eastop TD, McConkey A. Applied Thermodynamics for Engineering Technologists. (5th Ed.), Pearson Education Ltd.; 1993. p. 234-57.

[54] Geete A, Khandwawala AI. Thermodynamic analysis of $120 \mathrm{MW}$ thermal power plant with combined effect of constant inlet pressure (124.61 bar) and different inlet temperatures. Case Stud Therm Eng 2013;1:17-25.

[55] Forbus KD, Whalley PB, Everett JO, Ureel L, Brokowski M, Baher J, et al. CyclePad: An articulate virtual laboratory for engineering Thermodynamics. Artif Intell 1999;114:297-347. 